\title{
REWEAVING THE PLACE OF NATURE: TWO CONTEMPORARY WOMEN POETS ${ }^{1}$
}

\author{
IZABEL F. O. BRANDÃO \\ Universidade Federal de Alagoas/ Brazil
}

Recibido: 26/02/2013

Aceptado: 09/10/2013

\begin{abstract}
This article examines two women poets, the Brazilian Arriete Vilela and the Caribbean poet living in Britain, Grace Nichols, with the aim of showing the way they deal differently with notions of space and place in nature, approaching these notions through ecocriticism, feminism and other interdisciplinary readings.

Their poems present an understanding of nature that involves an interconnection between human and more-than-human in a relationship that may be seen as harmonious and problematic. Videla's use of "nature imagery" provides both resitances and potentialities to be revealed in her Brazilian poetry. Grace Nichols begins from a discontinuity in her view of Caribbean landscape and culture where a touristic colonizing industry frames even gendered bodies. These two poets explore the dialogue between external nature of the female human being, in a body of work through which such dialogues and conflicts can be poetically resisted and celebrated.
\end{abstract}

Key-words: contemporary women poets; place/space of nature; ecocriticism; feminism; interdisciplinarity.

\section{Resumen}

Este artículo analiza la obra poética de la escritora brasileña Arriete Vilela y de Grace Nichols, escritora caribeña afincada en Gran Bretaña. El objetivo es mostrar las

1. A shorter version of this article was first published in Portuguese in the Brazilian journal http://www.tanianavarroswain.com.br/labrys/labrysll/ecrivaines/izabel.htm, Accessed January-June 2007. The title is "Retecendo o lugar da natureza em poemas de autoras contemporâneas" ("Reweaving nature's place in poems of contemporary writers").

Feminismo/s 22, diciembre 2013, pp. 251-267 
diferencias en el tratamiento de las nociones de espacio y lugar en la naturaleza, a través de la ecocrítica, el feminismo y otras lecturas interdisciplinarias.

Sus poemas presentan un modo de comprender la naturaleza que implica una interconexión entre lo humano y lo más-que-humana en una relación que puede considerarse tan armoniosa como problemática. El uso que hace Vilela de "la imaginería naturalista" nos evoca las resistencias y, a la vez, potencialidades que pueden encontrarse en su poesía brasileña. Grace Nichols comienza desde la discontinuidad en su visión del paisaje y la cultura caribeños, donde una industria turística colonizadora prevalece incluso por encima del género de los cuerpos. Ambas autoras inician el diálogo entre la naturaleza externa y la naturaleza de la mujer, en obras en donde diálogos y conflictos pueden ser rechazados y celebrados a través de la poesía.

Palabras clave: poetisas contemporáneas; lugar/espacio de la naturaleza; ecocrítica; feminismo; interdisciplinariedad. 


\section{Literature and nature: the site of theoretical connections}

What may be surprising to readers outside the context of Brazil is that it is necessary to start this essay with the fundamental question that addresses the relationship between literature and environment. For most Brazilian literary scholars the connection is still far from obvious. If one were to search for a possible answer one need look no further than this very page in the printed journal that you are now reading. A "real" material journal, that is not delivered online, out of virtual space, provides a first answer in the very material you hold in front of you between your fingers. How many trees, one could ask, were needed for the paper production prior to the printing of the ecofeminist special issue of this journal? Once this connection is established we must consider deforestation, or we could think of the so-called "sustainable exploitation of natural resources" that makes use of reforesting for the production of cellulose. Thus, in front of our eyes is an ecofeminist journal that may be collaborating in the destruction of nature, or a journal that escapes such a condition. For us in Brazil this is more than a local or national consideration, but one with global implications, especially for these who do not live in the "First World" and daily confront the consequences of global environmental actions and attitudes.

This is an example of one of the many questions posed by ecocriticism, a field of contemporary literary criticism that has been renewing the air of academic research in literature for the past three decades in America and Europe, and is only now renewing literary studies in Brazil. One of the critics whose thinking about the relevance of such a discussion has inspired the beginning of this article is Glen Love, in his Practical Ecocriticism, published in 2003 but still, like so many key texts, with no translation into Portuguese. ${ }^{2}$ For him, teaching and research in the field of literature are cultural activities that take place within the context of a biosphere, "the part of the earth and its atmosphere in which life exists". ${ }^{3}$ Thus, there is a direct relation between

2. See Love, G. Practical Ecocriticism: Literature, Biology, and the Environment Charlottesville and London, U. Virginia Press, 2003, p.16.

3. Love, Op. Cit., p.16. 
literature, nature and ecocriticism, which is embedded in the printed paper of the page we read. Such a perception helps in translating an implicit dialogue between the literary text and the environment that surrounds us, as Love suggests. However, there are obstacles, for "Ecocriticism is developing as an explicit critical response to this unheard dialogue, an attempt to raise it to a higher level of human consciousness". ${ }^{4}$ Then it is possible to say that studying and teaching literature cannot ignore "the natural conditions of the world and the basic ecological principles that underlie all life", for this would become "short-sighted, incongruous". ${ }^{5}$ A similar understanding is posed by ecofeminists such as Diamond and Orestein ${ }^{6}$, Gaard and Murphy ${ }^{7}$, and other ecocritics such as Glotfelty and Fromm ${ }^{8}$, who propose an interdisciplinary connection between the varied fields of knowledge, as in nature, as ecology teaches us.

But still, such a theoretical development, which I have characterized as a renewal within literature, is relatively recent, and even though we may recognise that it has quickly gathered momentum in "First World" countries, in Brazil, where I live, teach and research in this field, such a development is still far too partial. It is restricted to a few literature researchers, such as Angélica Soares, from Federal University of Rio de Janeiro, a pioneer in the field who started reading literature through the perspectives of ecology in the early 1990s in Brazil. Her book Ecologia e literatura ("Literature and Ecology") dates back to 1992, taking its impetus from the world conference Eco $92^{9}$ on the environment, held in Rio de Janeiro that year. ${ }^{10}$ In 1999, she has published A paixão emancipatória ("The Emancipatory Passion"), a book about the poetry of contemporary Brazilian women poets which has a chapter dedicated to the relationship between nature and literature. ${ }^{11}$

4. LOVE, Op. Cit., p.16.

5. LOVE, Op. Cit., p.16.

6. DIAMOND and ORESTEIN (eds) Reweaving the World: The Emergence of Ecofeminism. Sierra Book Clubs, 1990.

7. GAARD, Greta and MuRPHY, Patrick D. (eds). Ecofeminist Literary Criticism: Theory, Interpretation, Pedagogy. Urbana and Chicago, University of Illinois Press, 1998.

8. Glotfelty, C. and Fromm, H (eds). The Ecocriticism Reader: Landmarks in Literary Ecology. Athens, The University of Georgia Press, 1996.

9. In 2012, twenty years after Eco 92, Brazil hosted the international Rio +20 .

10. SOARES, A. (ed.). Ecologia e literatura. Rio de Janeiro, Tempo Brasileiro, 1992.

11. See SoARES, A. A paixão emancipatória. Rio de Janeiro, Difel, 1999. The reference is just to Soares because until recently I have not heard of any other researchers in Brazil who work within the field of ecocriticism (or ecofeminism for that matter). Back in 2003 in my article "Ecofeminismo e literatura: novas fronteiras críticas" "Ecofeminism and Literature: New Critical Borders", published in BRANDÃO, Izabel \& MUZART, Zahidé [eds]. Refazendo nós: ensaios sobre mulher e literatura. Florianópolis/ Santa Cruz do 
This article is intended as a contribution to this theoretical and critical renewal, especially in relation to the Brazilian context and, more modestly, for the international reach of Feminismo/s within Europe and elsewhere. I have been researching within the field of ecocriticism since 2002, thanks to the influence of Terry Gifford who first introduced me to the field when I was in England doing my doctoral research in the early nineties, and who also introduced to me the work of the Caribbean poet Grace Nichols, whom he considers one of the contemporary "green poets" writing in England since she settled there in 1977. ${ }^{12}$ My research takes an interdisciplinary feminist approach in dialogue with ecocriticism and ecofeminism, as well as many other writers whose critical perceptions are useful, such as Bachelard, Foucault and Augé, among others. Such interdisciplinary focus has been reinforced within feminism in Brazil by feminists Claudia Lima Costa and Simone Schmidt ${ }^{13}$, and this is also consolidated as sine qua non part of ecocriticism, for no field of study can assume to hold knowledge of all areas, as Glotfelty and Fromm indicate. ${ }^{14}$ It is from this perspective that Glen Love argues that literary scholars "for the most part have stayed on their side of the humanist-scientist

Sul, Mulheres e Edunisc, 2003, p.461-473), besides Soares, I refer to a Masters Thesis on Margaret Atwood, by Luciana Labatti Teixeira, defended at Federal University of Minas Gerais, whose theoretical framework is ecofeminism. In 2005 in the national conference of Abrapui (Brazilian Society for University Teachers and Researchers of English), held in Fortaleza, one of the keynote speakers was the postcolonial ecocritic Graham Huggan, from the University of Leeds, England. In this same conference, my own contribution was about the Caribbean poet Grace Nichols, offering an ecofeminist reading of her poems. This paper was later published in Portuguese in $O$ corpo $\mathrm{em}$ revista, a book I edited (2005) and in English in the Italian literature Journal Englishes (2007). In August 2012, Federal University of Paraiba hosted its First International Conference on Ecocriticism. I understand that the field of research is expanding in Brazil, but the expansion is still slow.

12. GIFFORD, T. Green Voices: Understanding Contemporary Nature Poetry. $2^{\text {nd }}$ edition, CCC Press, 2011, pp. 175-177 [Manchester, Manchester University Press, 1995].

13. See Costa, C. L.; SChmidt, S. (eds). Poéticas e políticas feministas. Florianópolis, Mulheres, 2004.

14. See Glotfelty, C. \& Fromm, H, Op. Cit. The essay "Feminist Ecocriticism: The New Ecofeminist Settlement", by Serpil Oppermann, in this volume of Feminismo/s, discusses in depth the conceptual redefinition of notions such as ecofeminism within the field of study of ecocriticism. I believe that it is desirable that such a discussion of the concept of ecofeminism be associated with a more global understanding of the field. The use of feminist ecocriticism seems to me more open and helpful for those who feel more akin towards a realignment of the concept with contemporary feminist theories, expanding its meaning as Gaard (qtd by Opperman) suggests: "feminist ecocriticism affirms the necessity of a new feminist perspective in environmental literatures, cultures, and science studies". My thanks to Kerslake and Gifford for sharing other contributions to this journal ahead of publication.

Feminismo/s 22, diciembre 2013, pp. 251-267 
barrier, limiting their focus to metaphor and language while ignoring the exciting interdisciplinary opportunities that beckon". ${ }^{15}$

The second relevant question for this article is in which form nature is being dealt with in contemporary literature? Having poetry in mind, Love attempts an answer:

A wave of new nature poetry has been a response to the age of ecology, as the aspect of an inexhaustible and constant nature is replaced by one of vulnerability and of recognition that our cultural identity rests uneasily upon deeper responsibilities. ${ }^{16}$

If such a question is being dealt with in Brazilian literature this is something yet to be revealed by recent research trends. What it is possible to say, however, is that literature, in a general way, attempts to provide answers to questionings that are provoked by nature, be it human or non-human, to which all of us belong. Focusing upon women's poetry, the two poets chosen for this article, Arriete Vilela and Grace Nichols, Brazilian and Caribbean poets respectively, perceive nature in a very provocative way and interlace the human and non-human by means of a knot of continuity which is revealing of the interconnection of beings, as I hope to demonstrate.

\section{Arriete Vilela's poetry: dialogues with nature ${ }^{17}$}

Arriete Vilela is a Brazilian poet born in Marechal Deodoro, in the northern coastal area of the state of Alagoas, in the Northeast of Brazil. Her style is marked by a strong preoccupation with the word, with the preciseness of suggestibility that can be extracted from it, avoiding what she characterizes as "adornments", "narrow ribbons" and "remnants". Arriete Vilela has established herself as a writer in Alagoas where her work is known and studied since, in 2005, it was launched in the Brazilian literary market through the publication by Gryphos of her first "novel", Lãs ao vento ("Wool in the Wind"). ${ }^{18}$ This "novel", which was awarded the International Literary Prize for Brazil-Hispanic American Litereature (Prêmio Internacional de Literatura Brasil-América Hispânica), is a prose narrative, but represents a distinctive effort of connectivity by the writer in maintaining a hybrid kind of work

15. LOVE, Op. Cit., p.32.

16. Love, Op. Cit., p.33.

17. A part of this section of the essay was taken from a book chapter titled "A poesia de Arriete Vilela: diálogos com a natureza", published in Portuguese, in 2007. See. Moraes, M. H. M. Poesia alagoana hoje. Maceió, Edufal, 2007, p. 119-140.

18. Vilela, A. Lãs ao vento. São Paulo, Gryphos, 2005. 
through narratives that skirt poetry and are situated on a very thin threshold between one mode and another.

For this article I have selected a number of poems that could represent a Brazilian contemporary writer and poet within the so-called framework of the Anglo-American genre of so-called "nature writing". Vilela's poems make use of nature images and metaphors and the term "nature" here indicates not only nature external to the human being. It is also in the tendency of this writer to be forcefully aware that her interconnection with the outside world defines her being and should not be ignored. This is, of course, one of the fundamental laws of ecology, according to the pioneering work of Rueckert as regards literature's need to engage with the interconnection of all things in nature. ${ }^{19}$

For the Brazilian poet, the presence of the natural world indicates a degree of intimacy that can be characterized as greater or lesser, pending on the state in which feelings are summoned by the poem. Human and non-human are interconnected through a language that builds an equation that might lead to harmony and/or disharmony with the Other. The poetic persona adopted by Arriete Vilela is endowed with clothing that can insinuate animals - somehow going back to what Gaston Bachelard defines as the phenomenology of aggression - proceeding from the use of images of claws, stings, beaks, wings, or of other elements present in nature, such as stones, flowers, fruits, pollen - all pointing to the human's rich and complex connection with external nature. ${ }^{20}$ The images also unveil the interior of the human being, which shows itself through elements which are peculiar to the experience of a child and the poet's childhood. Her memory often comes to the fore in the poem by invoking scents or secrets which are safely guarded in shoe-boxes from which the memories jump out. Such a connection can also spring from the summoning of passion from her suggestive use of words, and, here, the poet shows her more seductive side, in the sense that she traces in language the echoes of a love relationship, whatever its outcome, for the worst or the best.

From multiple poetic instances, the selected poems for this analysis show, if not a seamless continuity as such, a strongly luxurious relationship between the female human being and the natural world in which a "biodiversity" is created by means of the struggle with (or against) the words themselves.

19. See RUECKERT, W. "Literature and Ecology: An Experiment in Ecocriticism". In GlotFELTY, C. and H. FROMm (eds.). The Ecocriticism Reader: Landmarks in Literary Ecology. Athens and London, The University of Georgia Press, 1996, pp.105-123.

20. See Bachelard, G. Lautréamont. Paris, José Corti, 1939.

Feminismo/s 22, diciembre 2013, pp. 251-267 
A rede do anjo ("The angel's hammock"), published in 1992, is Vilela's second book of poetry. ${ }^{21}$ The poems are mostly short and deal with, among other themes, the search for the word that defines the soul, which becomes almost an obsession in the writer's continuing works. ${ }^{22}$ Here she invites her readers to an intimate meeting where she will be divested of her defenses so as to allow a diving into her knowledge of herself, without the help of "haberdashery / striped ribbons / wavy ribbons".

Having her soul thus destitute of

[...] adornments

you may finally

know it.

$\left(\text { Poem n }{ }^{\circ} 7\right)^{23}$

It is possible to note, from these lines, the poet's successful attempt to make use of a precise, economical language, and it is poems like this that constitute the body of $A$ rede do anjo. There are other poems in the book whose number of lines is longer, but still, the language is clean and clear, making the reading agile and quick. It is perhaps only when we go back to the verses that we are able to acknowledge the subtlety of the self-exposure in Arriete Vilela's economic language.

The poems in A rede do anjo are not named. This is a recurring feature in Vilela's books. Such a tendency towards anonymity may be understood as an attempt to make it difficult to search for meaning, for, if we understand that we only name what we know, which involves a filter of affectivity (either for good or bad), her not naming the poems implies a certain distancing: the poems are just numbers rather than a list of evocative titles. Yet this is an illusion, for the revelation of meaning does not depend on this, despite the poet's apparent intention. It may be that what provokes "fractures among the words", according to what Arriete Vilela tells us in Vadios afetos ("Stray affects"), in a poetic introduction to the book in the disarming form of a

21. I consider 15 poemas de Arriete ("15 poems by Arriete"), published by DAC-SENECMEC, in 1974, as the poet's first book of poems. In 1971, she published Eu, em versos e prosa ("I in verse and prose"), by Tribunal de Contas do Estado de Alagoas, a mix of essays and poems. As recently as 2010, on her sixtieth birthday, the poet has published her Obra poética reunida ("Collected Poetic oeuvre") with Poligraf.

22. In Lãs ao vento ("Wool in the Wind"), the word becomes a character and conquers a body. If one goes back to Fantasia e avesso ("Fantasy and its inside out") from 1986, which is the poet's main book of prose writing, the word is the body of the narrative, but its context, if one relates it to the "novel" published in 2005, the connoted meaning is different. See my book Entre o amor e a palavra ("Between Love and the Word") where many chapters deal with this narrative.

23. All the translations of Vilela's poems are mine. 
"Quick chat" by the writer with her readers. Such "fractures" leave her "with an uncomfortable feeling of having been cheated within my own writing" (p. 6). The poet being "cheated" is what allows the reader to understand the many unsaid things in the poem printed on the page, whether the reader might identify with it, or deny it as distant from herself.

Poem $n^{0} 4$ is about the poet's need (her persona's need, that is) to be always in constant search inside herself, trying to know herself. Her inner nature - being inside herself for the sake of learning - is the necessary factor for "conferring" with herself: "I confer with myself". It is in her return from this inner journey that outside nature emerges in order to offer images by which to report the findings concretely for the eyes of those who read her:

and when I emerge,

I'm a rock unveiled

by the retreating

tide

(my italics)

"Rock" and "tide" are the way the poet found to demarcate without abstraction the result of her incursion within herself. For Bachelard, in his studies about the earth, external surface elements present what he defines as a poetic of the will, of the extrovert imagination, as opposed to caverns and labyrinths, which imply a poetics of intimacy. ${ }^{24}$ When we consider the elements associated with the earth, such as the stone, or the rock, we encounter in the actual search itself a recognition of the resistance of matter: "If in the world of symbols the resistance is human, in the world of energy, the existence is material. ${ }^{25}$ Hence, Arriete Vilela finds from her searches in the earth the endorsement of the wish for resistance. The "retreating tide" that discloses the "rock", shows it as an image of defense hidden in her own being, which only comes to the surface whenever it is necessary. In terms of the poem, her emergence appears from the diving into her being in her search for knowledge, which is presented as stone, a matter of the resisting earth. So, a "concise" poem such as $n^{\circ} 4$ reveals itself as an immense metaphor for power, established in the natural world. Such a metaphor is nothing more than an expanded "potency for creation" in the image of the rock that let itself be disclosed by the low tide.

When we consider such an association - the human being = rock; human = non-human - it leads us to consider not only the power found in nature

24. See Bachelard, G. La Terre et les rêveries de la volonté and La Terre et les rêveries du repos. The translations into English are mine. Both books are published by José Corti, 1947 and 1946.

25. BACHELARD, G. La Terre et les rêveries de la volonté, p.16.

Feminismo/s 22, diciembre 2013, pp. 251-267 
which is transferred to the human being, but also the association between women and nature too, something that brings us back to the old problem of essentialism in the equation. ${ }^{26}$ Murphy's article in this volume of Feminismo/ $s^{27}$ quotes Vandana Shiva in relation to this connection, which she properly realigns towards a more meaningful sense that I would like to bring to my discussion of Vilela's poem: "[...] women and nature are associated not in passivity but in creativity and in the maintenance of life". The poem discloses a defense mechanism which the human beings - women and men alike develop in order to find within themselves the way out of difficult situations. The poem shows us an image which discloses a rock in the low tide. This disclosure indicates that once one is "attacked" (in this case referring to a dying love affair), she either strengthens herself by becoming a rock or gets ready for battle - or both. There is no passivity in the association, the relationship, or the organic/emotional processes of which it is part.

In an article published in 2001 about Vilela's poetry, I discussed the poetics of aggression in $O$ ócio dos anjos ignorados ("The leisure of the forgotten angels"), from 1995. ${ }^{28}$ This book is to date, in my opinion, the core of the opus of the Brazilian poet, even if one considers the quality of her poetry books published either before or after $O$ ócio dos anjos ignorados. From this book I chose Poem $n^{\circ} 31$, because of the connection with the natural world which brings to the fore the theme of passion turned towards the word itself, which becomes the object of the poem; it (in Portuguese the word "poem" is gendered in the feminine; it is a "ela", or a "she") is the beloved being transformed into food and drink. The word becomes a

fried carapeba ${ }^{29}$

coral crab

and beer[,]

a tasty combination whose savoring invokes the colors white, from the fish; the energetic orange, from the coral crab; and the golden tone of the cool beer, drunk, obviously, in a scenery of luscious beauty, on the banks of the lagoon

26. My article "Ecofeminismo e literatura: novas fronteiras críticas", Op. Cit., discusses in depth the debate around the essentialist question posed in the association of women with nature.

27. See Patrick Murphy's essay "The Ecofeminist Subsistence Perspective Revisited In An Age Of Land Grabs and its Representations in Contemporary Literature" in this volume.

28. "The poetry of aggression in O ócio dos anjos ignorados" is in Entre o amor e a palavra: olhar(es) sobre Arriete Vilela (Maceió, Catavento 2001), which I have edited.

29. The carapeba is a fish which is quite popular in the area of Marechal Deodoro where the poet was born. Its scientific name is Diapterus Rhombeus or Gerres Cinereus. 
"displaying from the water flowers, the lilac one". ${ }^{30}$ Besides, the alliteration in Portuguese of the "r" which occurs in the stanza calls one to laughter, inviting the reader to the joy of a relaxing moment surrounded by beautiful scenery.

It is helpful to recall here that the erotic is one of the themes of ecofeminism. Gaard asks, for example, how the erotic is shown in the literary text; or how is it approached $?^{31}$ In the poem above, the erotic appears as a force that imposes on the word its becoming the body of writing, and as such, it may be "eaten", "drunk", "savored"; it is the word dressed as fish-crab-lilac water flower, that, in Bachelard's terms, "tonalises" the poet's eyes taking her to this poetic banquet. The beer-word, drunk on the banks of the lagoon, is also fed by the color green, characteristic of the water flowers that border the lagoon as well as the flowers that are characteristic of that wider region.

In this poem, differently from others in the poet's oeuvre, nature does not appear as a space dedicated to loneliness and the acquiescence of passion. On the contrary, the word looks to love for it to be casual, full of good humor and joy, as a newly born passion. As such, it becomes a

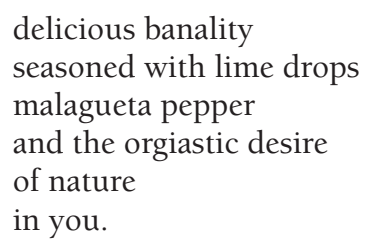

In sum, the poetic dealing with the word is like a newly-born passionate love and the meeting with it is the seduction that leads it to become the loved body, the desired body "and the orgiastic desire / of nature / in you". This "you" obviously materializes nature into a person of flesh and bones.

Vilela harmoniously communes with the natural world in her search for a homeopathic healing for herself. A new love - a "free passion" - becomes the balm - parsley and arnica - to heal the "bleeding" of the bygone love. And perhaps it is not too much to note that it is not any love that it heals: this is a wild and tiny parsley, that is, a condensed ointment to heal the deep wounds of love in the past. Such a connectivity with nature here is crucial for the poet.

The poet's struggle with words leads her to use images of the material and natural world according to the feeling that she evokes in the construction of

30. The water flowers referred to by the poet are peculiar to the Mundaú lagoon in Marechal Deodoro. They spread around the water and look as though they were put there for decorative purposes.

31. GAARD, G. and MURPHY, P. D. (eds). Ecofeminist Literary Criticism: Theory, Interpretation, Pedagogy. Urbana and Chicago, University of Illinois Press, 1998. 
the poem, in her search for harmonizing and reweaving her knowledge of being. This is a hard struggle: arduous, but also pleasurable. It is like a sunny day, that may shine, may warm one up, but that may also burn. It is a fight that recalls another Brazilian poet, Carlos Drummond de Andrade, whose fight with words is notorious to the point where his critics call it a "Drummondian struggle", as Vilela herself acknowledges. Or, in her own words: "This clash is akin to / a walk along the sea shore / no breeze / under the midday sun" (Poem 65).

\section{Grace Nichols' poetry and nature in the body ${ }^{32}$}

Nichols' poetry is still not well-known in Brazil. Questions of race/ethnicity, class, gender and language are but a few of the prisms through which she may be read. For this article I have chosen the poem "On Receiving a Jamaican Postcard" for, besides the question of race/ethnicity, it also deals with questions related to the body, as well as others related to technology, for example, within her text.

Superficially the poem does not deal with anything particularly related to the body. However, it invites the reader to imagine an idealized space, almost a paradise where any couple may rest, dance, lay on the generously sunny Caribbean beaches, make love (or have sex) and be entertained by the dancing "natives".

colourful native entertainers

dancing at de edge of de sea

a man-an-woman combination

choreographing

de dream of de tourist industry

Here the idealized view of the touristic industry is transformed into a political metaphor: the Caribbean country is a place for primitive "natives" who are ready to serve the colonial tourist. The "gentle wit" referred to by Gifford ${ }^{33}$ as regards Nichols' poetry is more than gentle in this poem, for she acidly criticizes the photographer's colonialist view in "fabricating" a narrative to serve the touristic colonizing industry. Everything is false: from the "man-anwoman combination" to the choreographed dance. The intention is merely to satisfy the commercial interests of an industry whose only purpose is to

32. A longer analysis of this and other poems by Nichols appear in my "Grace Nichols e o corpo como poética da resistência", a chapter of BRANDÃO, I. (ed.). O corpo em revista - olhares interdisciplinares, Maceió, Edufal, 2005.

33. See Gifford, Terry. Green Voices: Understanding Contemporary Nature Poetry. $2^{\text {nd }}$ edition, CCC Press, 2011, p 175 [Manchester, Manchester UP, 1995]. 
attract the foreign visitor to a "primitive" place, where what is advertised the paradisal touristic resort - is ritualized, and the body (from the country itself to the tourist men and women) becomes an object to be consumed as goods to be sold and bought by anyone with money. The focus of the poem is, therefore, about the hindrance imposed by the colonizing culture within Caribbean external nature as well as within the human nature of the Caribbeans who are represented by the dancers.

For Gifford, Nichols' 'green voice' is "politicized, witty and exploring what it means to live with the constructions of nature located in two places". ${ }^{34}$ This double construction takes the reader to the ambivalence felt by the poet with what she sees in the Jamaican postcard. As the addressee of this card, she may be thought of as the one who left that country to live in a different one, demarcating thus a diasporic movement. ${ }^{35}$ Her feeling of nostalgia can be seen at once in the third and fourth stanzas where the poet uses the politics of a different english (with a small "e") through the missing sounds such as the "th" that is shown through "de": "an de sea so blue / an de sky so blue / an de sand gold fuh true" (my italics). ${ }^{36}$ Here Nichols demarcates her "Existential Territory" ${ }^{\prime 3}$, that is a place where one is free to use one's own language without the colonizer's interference. This very feeling can be seen in other verses of the poem: "wid" instead of "with", "he" instead of "his", "riddum" instead of "rhythm", "lil mo" instead of "little more". Thus, language is also a metaphor for the nostalgia felt by the poet in relation to her homeland which she left behind. This leads to the notion of resistance, departing from the "body" of language.

This poem is not exactly postmodern as such, but it is possible to capture in its narrated story elements which originate from the notion of photography as art, which may be seen as social practice, even if related to the selling of an

34. GIFFORD, Op. Cit., p. 177.

35. See Aschroft, B., G. Griffiths and H. Tiffin. Key Concepts in Post-Colonial Studies. London and New York, Routledge, 1998.

36. It is possible to associate the longing expressed in the language of the poem with what has been termed by E. K. Brathwaite (1979) as "nation language", a political use of the language of the colonizer by the once colonized peoples (MCLEOD, J. Beginning Postcolonialism. Manchester, Manchester UP., 2000, 25). See also BRATHWAITE, E. K. "From History of the Voice" in THIEME, J. (ed.). The Arnold Anthology of Post-Colonial Literature in English. London, Arnold, 1996.

37. The concept of Existential Territory is taken from Angélica Soares' reading of Deleuze and Gattari, which is "um espaço de ressingularização da experiência humana" ( $O p$. Cit, p.56), meaning "a space of re-singularization of human experience" (my translation), or a place of resistance in which the subject locates him/herself. This is the sense which I associate with Nichols' poetry. 
image for ideological or more obscure reasons. For Connor it is possible that a narrative is present or absent in a photograph: any photograph "inescapably implicates a world of activity, responsible for, and to, the fragments circumscribed by the frame: world of causes, of 'before' and 'after', of 'if, then...', a narrated world". ${ }^{38}$

This "narrated world" is implicit in the poem under analysis: it is a world about which one feels nostalgia (the words are witnesses of this because of their changed sounds), but one may also criticize. The couple symbolize the subliminal objective of the touristic industry, that is to 'conspire' to obtain more visitors, and as a consequence, more money. The poem's representation of colonized nature versus colonizing culture exhibits the open wound of the heritage of colonial exploitation and the chronic poverty of West Indian countries whose "native entertainers" are also an advertisement to attract potential visitors.

The image also shows us that the photographer succeeded in revealing through the dancing couple "a smiling conspiracy / to capture the dream of de tourist industry". This is a dream of exploitation ("Anything fuh de sake of de tourist industry / Anything fuh de sake of de tourist industry") and presents more implications than the mere colonizing view of two "natives": both "man-an-woman" are also there to show their bodies as commodities to be sold along with the landscape.

he staging a dance-prance

head in red band

beating he waist drum

as it he want to drown she wid sound

an yes, he muscle looking strong

she a vision of frilly red

back-backing to de riddum

exposing she brown leg

arcing like lil mo

she will limbo into de sea

(my italics)

For this reason, the Jamaican "natives" are there selling a dream for the new look for the neo-coloniser, as defined by the photographer's eye. This is the narrative which is implicit in this postcard: it is a political narrative that shows nature human and non-human alike being exploited in a double way, for it shows another feature of the exploitation that is in the eyes of the marketing

38. CONNOR, S. Postmodernist Culture: An Introduction to Theories of the Contemporary. London, Basil Blackwell, 1989, p.106 (original italics). 
industry, whose intention is to attract consumers to live in a world that is false and idealized. The medicine Nichols brings to the body (including the eye) is resistance. Therefore the poem suggests that the politics of resistance seems to be the only way out of our consumer and globalised society.

To close this article, I would like to go back to the questions raised in the beginning: the relation between nature and literature happens because we cannot separate the world of scholarship from the "real" world as though the literary representation could have an existence apart from everything else. I share with Glen Love (2003) the sense that human beings are unique in nature in their interest in the arts and literature. The questions posed by ecocriticism, and by a feminist ecocriticism especially, propose the problematizing of the nature of the body of writing, of the language that constitutes the literary text.

The choice of the poets briefly studied here was guided by the sense that the literature produced by women in the contemporary world has revealed their contribution to culture in an exemplary way and, ideologically, has also demarcated their place in a critical way, delicately but strongly politicizing the context of their writing in poetry and prose. The natural world appears dialogically with the human, but this is not always a harmonious dialogue, as has been noted in the poems chosen for analysis. If Arriete Vilela, on the one hand, shows joy in the relation between word/nature/passion/conflict, exploring the human being's core as a possible mirror for nature, Grace Nichols, on the other hand, politicizes the debate in her verses, when she confronts the cultural colonizing wish to maintain the people who were once colonized in a condition of permanent exploitation. Hence, these two poets show the interconnection between external nature and the nature of the human being in dialogue with the non-human, which interacts through language in a body of work through which such dialogues and conflicts can be poetically posed, considered, resisted, celebrated.

\section{Bibliographic References}

Alaimo, Stacy. The Undomesticated Ground: Recasting Nature as a Feminist Space. Ithaca and London, Cornell U 2000.

Aschroft, B., G. Griffiths and H. TifFin. Key Concepts in Post-Colonial Studies. London and New York, Routledge, 1998.

BACHELARD, Gaston. Lautréamont. Dallas, The Pegasus Foundation, 1986 [1939]. 
BACHELARD, Gaston. La Terre et les rêveries de la volonté Paris, Librairie José Corti, 1947.

BaCHElard, Gaston. The Poetics of Space. London, Beacon Press, 1965 [1958].

BHABHA, Homi.[1994] The Location of Culture. New York, Routledge, 1994.

BRANDÃO, Izabel. Re-significação e retecimento do lugar do corpo na literatura: considerações teóricas iniciais. In CaVAlCANTI, Ildney, Lima, Ana Cecília A. e SCHNEIDER, Liane (eds). Da mulher às mulheres: dialogando sobre literatura, gênero e identidades. Maceió, Edufal, 2006, p. 134-147.

BRANDÃO, Izabel. Grace Nichols e o corpo como poética da resistência. In BRANDÃO, Izabel (ed.). O corpo em revista: olhares interdisciplinares. Maceió, Edufal, 2005, p.99-122.

BRANDÃO, Izabel. Ecofeminismo e literatura: novas fronteiras críticas. In BRANDÃO, Izabel \& MUZART, Zahidé (eds). Refazendo nós: ensaios sobre mulher e literatura. Florianópolis/ Santa Cruz do Sul, Mulheres e Edunisc, 2003, p. 461-473.

BRANDÃO, Izabel. A poesia da agressão em O ócio dos anjos ignorados. In BRANDÃO, Izabel (ed.). Entre o amor e a palavra: olhar(res) sobre Arriete Vilela.. Maceió, São Paulo, Catavento, 2001, p. 185-195.

Brathwaite, E. K. "From History of the Voice". In Thieme, J. (ed.). The Arnold Anthology of Post-Colonial Literature in English. London, Arnold, 1996.

BuEll, L. The Future of Environmental Criticism: Environmental Crisis and Literary Imagination. Oxford, Blackwell, 2005.

Connor, Stephen. Postmodernist Culture: An Introduction to Theories of the Contemporary. London, Basil Blackwell, 1989.

Foucault, Michel. 1984. Outros espaços. In Motta, Manoel Barros de (ed.). Michel Foucault: Estética: Literatura e pintura, música e cinema. Trad. Inês Autran Dourado Barbosa. Rio de Janeiro, Forense universitária, 2001, pp. 411-422.

FouCAult, Michel. 1971. A ordem do discurso. $1^{\text {a }}$ ed. Trad. Laura Fraga de Almeida Sampaio. São Paulo, Edições Loyola, 2006.

GAARD, Greta and Patrick D. MURPHY (eds). Ecofeminist Literary Criticism: Theory, Interpretation, Pedagogy. Urbana and Chicago: University of Illinois Press, 1998

GIFFORD, Terry. Green Voices: Understanding Contemporary Nature Poetry. $2^{\text {nd }}$ edition, CCC Press, 2011 [Manchester, Manchester UP, 1995].

GlotFelty, C. and H. Fromm (eds). The Ecocriticism Reader: Landmarks in Literary Ecology. Athens, The University of Geórgia Press, 1996.

LOVE, Glen A. Practical Ecocriticism: Literature, Biology, and the Environment. Charlottesville and London, University of Virginia Press, 2003.

MCLEOD, John. Beginning Postcolonialism. Manchester, Manchester UP., 2000.

Nichols, Grace. Lazy Thoughts of a Lazy Woman. London, Virago, 1989. 
Nichols, Grace. "Free Verse". In The Guardian, 16/10/1991.

Rosendale, Steven. (Org.) The Greening of Literary Scholarship. Iowa, Iowa University Press, 2002.

SOARES, Angélica. A paixão emancipatória. Rio de Janeiro, Difel, 1999.

VILELA, Arriete. A rede do anjo. Maceió, s/e., 1992.

VILELA, Arriete. O ócio dos anjos ignorados. Maceió, s/e, 1995.

VILELA, Arriete. Obra poética reunida. Maceió, Poligraf, 2010. 